\title{
SHORT COMMUNICATION: GENOMIC CONSTITUTION OF OIL PALM INTERSPECIFIC HYBRID CROSSES MONITORED BY GENOMIC in situ HYBRIDISATION (GISH)
}

\author{
MADON, $M^{*}$; ARULANDOO, $\mathrm{X}^{* *}$; SRITHARAN, $\mathrm{K}^{\star *}$; NORDIANA, H M N*; \\ MUHAMMAD AZWAN, $Z^{*}$ and MOHD ZAKI, $\mathrm{N}^{*}$
}

\begin{abstract}
Interspecific hybridisation of Elaeis oleifera $(O)$ and Elaeis guineensis $(G)$ oil palm was done to create recombinant progenies, containing various composition of parental genetic material. Genomic in situ hybridisation (GISH) on OxG hybrids had previously shown presence of 16 E. oleifera and 16 E. guineensis chromosomes. In this study, GISH was used to examine the metaphase chromosomes of the OxG interspecific hybrids hybridised with E. guineensis $[(O x G) x G]$ to produce backcross one $\left(B C_{1}\right)$ progenies. Optimisation of unlabelled E. guineensis genomic DNA quantity were required to produce optimum discrimination of the E. oleifera and E. guineensis chromosomes. The amount needed was 120 $\mu g$ indicating the high genome similarity. The chromosomes of $B C_{1}$ individuals were $2 n=32$ and consisted of variable composition of E. oleifera and E. guineensis chromosomes while the interphase nuclei showed regions of parental genomes in discrete, non-intermixed domains indicating non-random organisation of the nucleus. The seedlings were created to assist in GISH analysis, hence, only leaflet plane correlation with the number of E. oleifera chromosomes transmitted into the progenies were done. No correlation can be observed between the numbers of E. oleifera chromosomes and the leaflet plane.
\end{abstract}

Keywords: GISH, Elaeis guineensis, Elaeis oleifera, interspecific hybrids, backcrosses.

Date received: 29 September 2017; Sent for revision: 2 October 2017; Received in final form: 26 March 2018; Accepted: 30 April 2018.

\section{INTRODUCTION}

In year 2017, Malaysia produced 19.92 million tonnes of crude palm oil (CPO) from 5.81 million hectares E. guineensis palms, resulting in the export of 16.56 million tonnes of palm oil products (Kushairi et al., 2017). A high percentage of mono-cropping with a single species that is derived from a limited genetic background, can have repercussions if there is any disease outbreak. The first epidemic of bud rot in

Malaysian Palm Oil Board, 6 Persiaran Institusi, Bandar Baru Bangi, 43650 Kajang, Selangor, Malaysia. E-mail: hariza@mpob.gov.my

** Research Department, United Plantations Berhad, Jenderata Estate, 36009 Teluk Intan, Perak, Malaysia. oil palm in Colombia was reported in 1964 (Torres et al., 2016). Recent epidemics destroyed more than 70000 ha in western and central oil palm growing regions of Colombia. Planters had no choice but to replace E. guineensis with Elaeis oleifera $(\mathrm{O})$ and Elaeis guineensis $(\mathrm{G}) \mathrm{OxG}$ hybrids which are more tolerant to the disease. The bud rot is caused by Phytophtora palmivora and it is a destructive emerging disease of oil palm (Torres et al., 2016) and in the tropics, $P$. palmivora is a pathogen of many plant species. Hence, pursuing a breeding programme involving interspecific hybrids of oil palm, is important to manage any risk of mono-cropping with a single species.

Elaeis guineensis and Elaeis oleifera are the two species of oil palm and the oil palm breeders have 
successfully crossed these two species to produce OxG hybrids. The leaflet plane arrangement for E. oleifera is single and double for E. guineensis. Both species have $2 \mathrm{n}=32$ chromosomes which can be divided into Group I (pair No. 1), Group II (pairs No. 2-9) and Group III (pairs No. 10-16) (Madon et al., 1998). However, Singh et al. (2013) has re-assigned the 16 pairs of $E$. guineensis individual chromosomes into four groups; Group I; the largest chromosomes (hybridises to $5 \mathrm{~S}$ rDNA at the proximal); Group II: eight medium chromosomes; Group III; six small chromosomes, and group IV: small acrocentric chromosomes (hybridised to 18S-25S rDNA). E. guineensis produces higher oil yield compared to E. oleifera. However, E. oleifera produces a more unsaturated oil with higher carotene content with an added advantage of having slower stem growth and partial resistance to bud rot. The OxG hybrids, compared to E. guineensis, show a higher unsaturated oil content, lower height increment and the oil has a relatively high carotene content. The hybrids have a disadvantage of poor oil yield and vigorous vegetative growth making it difficult to harvest the fruit bunches. To improve these characteristics, OxG hybrids are backcrossed to its E. guineensis parent.

In OxG hybrids, Hardon and Tan (1969) found that bunch set, seedling germination and survival were all well below that of E. guineensis. In examining the inheritance pattern in the hybrid, dominance of E. oleifera was found for height increment, fruit shape and colour, parthenocarpy and arrangement of leaflets on the rachis, with over dominance of leaf length and size of leaflets (and possibly bunch yield). Intermediate values of parental were found for mesocarp content, shell and oil per fruit and chemical composition of the oil. Partial dominance of E. oleifera was observed in spikelet morphology and size of subtending bracts. A study conducted by Obasola et al. (1976) on a backcross programme of OxGhybrid with E. guineensis (tenera) as male parent, showed that the progenies are heterogeneous. The progenies fall into three morphological categories, those appearing like E. guineensis; like E. oleifera and combining characters of both species.

Genomic in situ hybridisation (GISH) was first developed by Schwarzacher et al. (1989) to discriminate the parental genomes of the intergeneric hybrid Hordeum chilense and Secale africanum. The use of labelled total genomic DNA (consisting of the entire DNA complement of a plant species) as a probe to chromosome spreads of interspecific hybrids has proved to be a useful technique. It permits discrimination of the genome origin of the chromosomes in hybrid plants and allotetraploid species and has wide application in plant breeding programmes (Heslop-Harrison et al., 1990). The use of total genomic DNA as a probe to chromosomes provides an effective way for parental genome analysis in both sexual and somatic interspecific hybrids. Intergenomic recombination chromosomes containing chromosome segments from both parental species can be readily identified, and their behaviour and transmission can be monitored through meiosis into the progenies as shown in Lilium interspecific hybrids and Elymus dahuricus (Kwon et al., 2017; Yang et al., 2017). Ramzan et al. (2017) has recently reviewed the application of GISH in horticultural plants and concluded that GISH has been used to perform chromosomal evaluation, cytogenetical classification, genomic constitution, polyploidy confirmation, hybrid verification and introgression breeding. In this study, the OxG hybrids were backcrossed using E. guineensis (tenera) as male parent for developing (GISH) method. Within the timeline of this experiment, only leaflet plane of progenies could be analysed for correlation with E. oleifera chromosome numbers transmitted.

\section{MATERIALS AND METHODS}

\section{Plant Material and Chromosome Preparations}

This study was initiated by creating crosses of the OxG hybrid individuals selected at random [Palms 66/23.91 (H66) and 80/23.91 (H80)] to the E. guineensis (T128) parent. These crosses produced two sets of backcross progenies:

(i) OxG hybrid $(\mathrm{H} 66) \times$ E. guineensis (T128) $\Rightarrow \mathrm{BC}_{1} 66$

(ii) OxG hybrid $(\mathrm{H} 80) \times$ E. guineensis (T128) $=>\mathrm{BC}_{1} 80$

In August 1996, the backcrosses seeds were received from United Plantations Berhad (Ulu Bernam, Perak, Malaysia). These seeds were then planted in small polybags and placed in the nursery. The roots were collected from seedlings when they were about one year old. The vigorous seedlings were replanted into large polybags and placed outside the nursery. When needed, the roots were collected, pre-treated and fixed (Madon et al., 1998). Eight seedlings each of $\mathrm{BC}_{1} 66$ and $\mathrm{BC}_{1} 80$ were selected at random for the GISH experiment.

\section{Extraction of Total Genomic DNA}

Total genomic DNA of E. oleifera (UP1026) and E. guineensis (T128) were used as probe and blocking agent, respectively. The DNA samples were extracted from the spear leaves using the CTAB (cetylmethylammonium bromide) method of Dellaporta et al. (1983). For each sample, $10 \mathrm{~g}$ fresh weight of leaves were used for DNA extraction.

\section{Preparation of Total Genomic Probe and Block}

The total genomic probe used in GISH experiments was derived from E. oleifera (UP 1026), and it was labelled with biotin molecules using 
Bionick Labelling Kit (Gibco BRL). The blocking DNA which was from E. guineensis (T128) was autoclaved for $5 \mathrm{~min}$ at 15 psi to break down the DNA into smaller fragments (100-300 bp). The labelling was carried out on $1 \mu \mathrm{g}$ of E. oleifera total genomic DNA. For GISH experiments on backcross (BC1 66 and BC1 80) progenies, $120 \mu \mathrm{g}$ DNA of E. guineensis was added as a block. These was followed by the addition of one-tenth volume of 3.4 $\mathrm{M} \mathrm{NaOAc}$, two volumes of $-20^{\circ} \mathrm{C}$ absolute ethanol before being stored at $-20^{\circ} \mathrm{C}$ until needed.

\section{GISH Protocol}

GISH and fluorescence microscopy protocols were modified from Schwarzacher et al. (1989) and Anamthawat-Jonsson et al. (1990). Prior to GISH, probe and block were mixed to a final concentration of $5 \mu \mathrm{g} \mathrm{ml}-1$ in a solution of $50 \%$ (w/v) formamide, $10 \%(\mathrm{w} / \mathrm{v})$ dextran sulphate, $0.1 \%(\mathrm{w} / \mathrm{v})$ SDS (sodium dodecyl sulphate) and 2xSSC (HeslopHarrison et al., 1990). Hybridisation sites were detected with fluorescein-isothiocyanate (FITC)avidin and chromosomes were counterstained with propidium iodide. The slides were screened using Carl Zeiss Axioplan epifluorescent microscope with suitable filters. Photomicrographs were taken using MC 80 camera system on KODAK 1600 ASA colour negatives or KODAK Ektachrome 1600 ASA colour slides, scanned into and printed from Adobe Photoshop only after contrast optimisation of images had been made.

\section{RESULTS AND DISCUSSION}

\section{GISH of Backcross Individuals $\left(\mathrm{BC}_{1}\right)$}

Some germinated seeds failed to grow and germinated seedlings of backcrosses were less vigorous in growth compared to normal E. guineensis (DxP, tenera) seedlings. These seedlings were small, and they were about one-third the size of normal DxP seedlings. Root samplings created stress and is suspected to have reduced the number of viable backcross progenies. Interspecific hybrid breeding in oil palm is intended to introgress desirable traits from E. oleifera into E. guineensis particularly in introgressing unsaturated oil with higher carotene content, slower stem growth and partial resistance to bud rot. However, in this study, the crosses were created to be used for development of GISH analysis in the nursery and hence the desirable traits were not measured.

It has been assumed that $\mathrm{OxG}$ hybrids contain 16 E. oleifera and 16 E. guineensis chromosomes and the genetic contribution of E. oleifera will be reduced by an average of $50 \%$ in each successive backcrossing to the E. guineensis parent. Each backcross cycle requires at least 10-12 years for the progenies to mature, before the next backcrossing is performed. During meiosis in OxG hybrids, each gamete receives variable composition of E. oleifera and E. guineensis chromosomes while maintaining $2 n=32$. In this scenario, GISH can be used to discriminate chromosomes of both species and ascertain the amount of E. oleifera genomes introgressed into OxG hybrids and their backcrosses and to look for introgressed chromosomes. For GISH of OxG hybrids, Madon et al. (1999) utilised the genomic DNA from E. oleifera as probe (labelled with biotin and detected with FITC) while $90 \mu \mathrm{g}$ E. guineensis genomic DNA as block. The results showed that the OxG hybrids contained 16 E. oleifera and 16 E. guineensis chromosomes.

Hence in this study, GISH technique was again applied to ascertain the introgression of $E$. oleifera genome into the interspecific backcross one progenies mainly to screen for the number of E. oleifera chromosomes in the backcross individuals. This information could be useful in assisting conventional plant breeding to improve selection criteria. It enables selection to be done earlier, and reduces the number of individuals selected for further backcrossing. GISH on the backcross individuals showed the presence of variable numbers of E. oleifera chromosomes [Table 1, Figure 1 (A1-C1)]. Due to meiotic process such as independent assortment and random pairing, the backcross individuals may consist of either totally E. guineensis or totally E. oleifera or a variable number of E. oleifera chromosomes. In this study, the backcross palms showed chromosome composition that are mostly from Group II and III chromosomes with $2 \mathrm{n}=32$. In interphase nuclei of OxG hybrids, chromosomes originating from the two different species occupy discrete, non-intermixed domains. This indicates that the interphase nucleus was not randomly organised (Madon et al., 1999). Similarly, in the interphase nuclei of $\mathrm{BC}_{1}$ the same events were observed [Figure 1 (A2-C2)]. Recombined chromosomes were difficult to observe due to the small size of oil palm chromosomes. Nonhomologous (intergenomic) recombination, somatic or meiotic, is desirable in plant breeding programmes in which the genetic base of a crop can be expanded by chromosome transfer from wild or another species of the same genus. The stable intergenomic pairing in meiosis ensures that meiotic disjunction proceeds correctly and that recombinant chromosomes could be carried to the gametes successfully, without being mechanically eliminated (Anamthawat-Jonsson and Bodvarsdottir, 1998).

\section{Correlation of E. oleifera Chromosome Numbers with Leaflet Plane}

The backcross individuals of OxG to the E. guineensis male parent showed differences in leaflet 


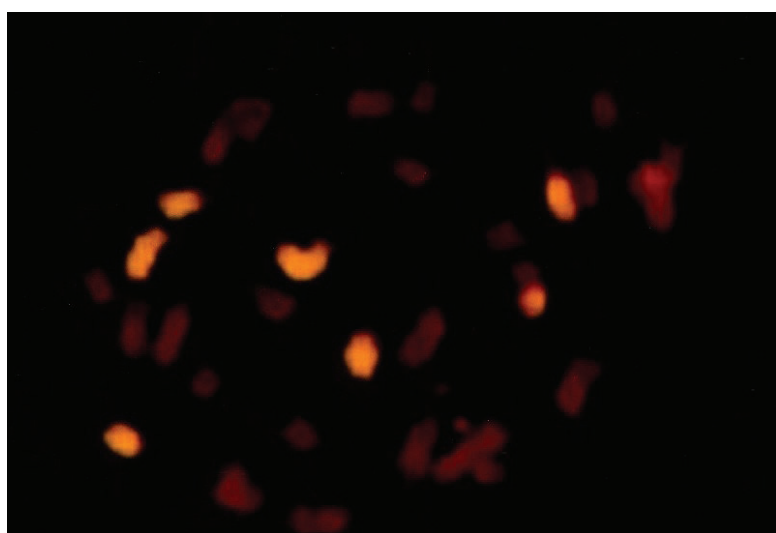

A1

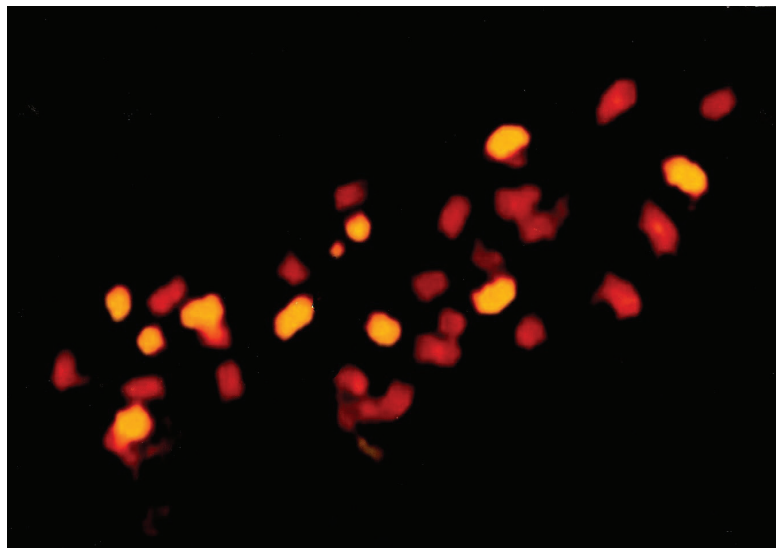

B1

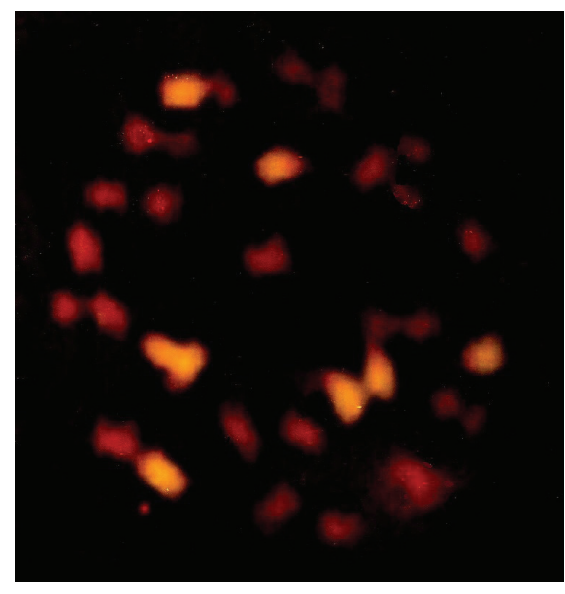

C1

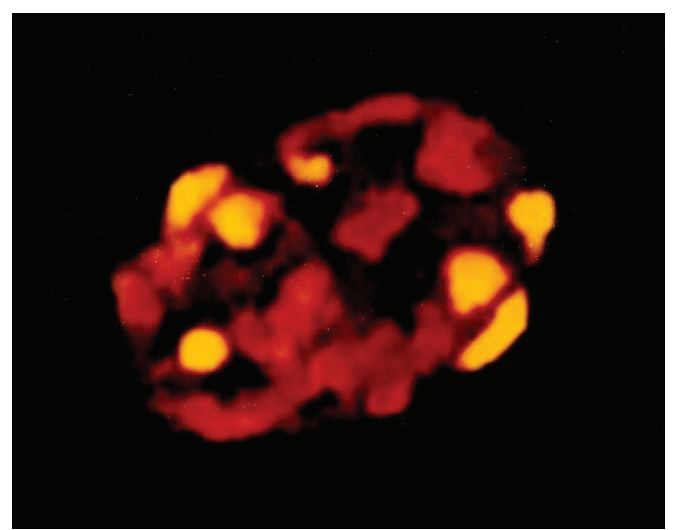

A2

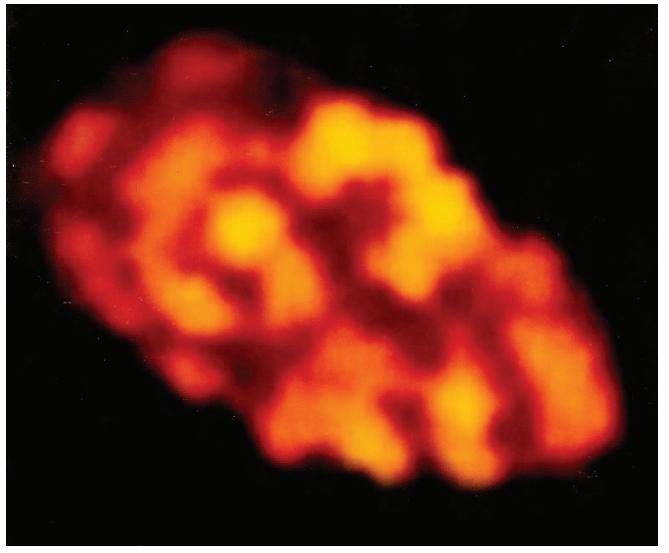

B2

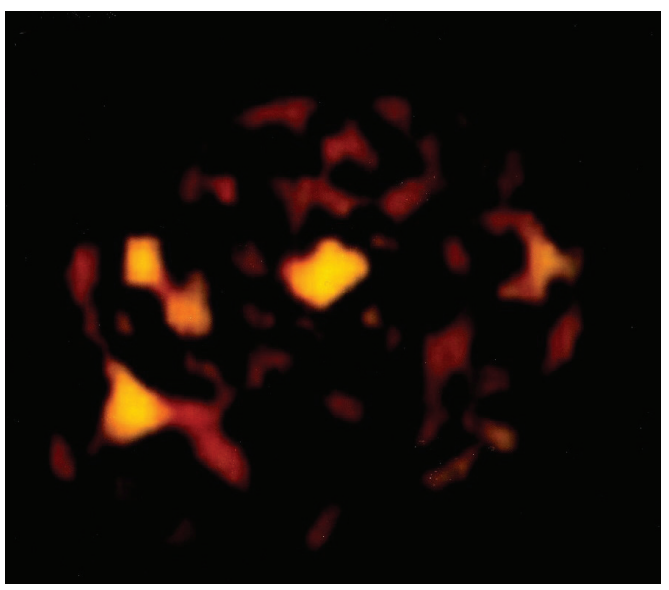

C2

Figure 1. (A1) Genomic in situ hybridisation (GISH) of backcross BC 66/\#7 showed 7 E. oleifera (yellow) and 25 E. guineensis (red), (B1) BC 66/\#18 showed $10 \mathrm{E}$. oleifera (yellow) and $22 \mathrm{E}$. guineensis (red) and (C1) BC 80/\#10 showed 8 E. oleifera (yellow) and $24 \mathrm{E}$. guineensis (red) chromosomes while (A2, B2 and C2) showed groups of chromosomes from both genomes occupying, discrete, non-intermixed domains.

arrangement. Progeny were scored as E. oleiferalike if their leaflet plane is single or E. guineensislike if the leaflet plane is double (Table 1, Figures $2 A$ and $2 B$ ). The backcross individuals used in this study were about 2 years and 4 months old. Most of the inheritance patterns mentioned earlier could not be studied at this time except for the leaflet arrangement trait. The OxG hybrids analysed in this study used E. oleifera as the female parent and E. guineensis (tenera) as the male parent and Meunier et al. (1976) found that the hybrid was closer to E. oleifera when the latter was the female parent but closer to E. guineensis when E. oleifera was the male parent. In agreement, the OxG hybrid were E. oleifera-like based on their single plane leaflet arrangements. However, the $\mathrm{BC}_{1}$ 
TABLE 1. LIST OF BACKCROSS INDIVIDUALS, LEAFLET PLANE AND CORRESPONDING NUMBER OF E. oleifera CHROMOSOMES.

\begin{tabular}{lcc}
\hline $\begin{array}{l}\text { Backcross } \\
\text { individuals }\end{array}$ & $\begin{array}{c}\text { Leaflet } \\
\text { plane }\end{array}$ & $\begin{array}{c}\text { Number of } \\
\text { E. oleifera } \\
\text { chromosomes }\end{array}$ \\
\hline $\mathrm{BC}_{1} 66 / \# 1$ & Double & Eight \\
$\mathrm{BC}_{1} 66 / \# 3$ & Double & Eight \\
$\mathrm{BC}_{1} 66 / \# 6$ & Single & Twelve \\
$\mathrm{BC}_{1} 66 / \# 7$ & Single & Seven \\
$\mathrm{BC}_{1} 66 / \# 15$ & Single & None \\
$\mathrm{BC}_{1} 66 / \# 17$ & Single & None \\
$\mathrm{BC}_{1} 66 / \# 18$ & Single & Ten \\
$\mathrm{BC}_{1} 66 / \# 21$ & Double & Five \\
$\mathrm{BC}_{1} 80 / \# 1$ & Double & Ten \\
$\mathrm{BC}_{1} 80 / \# 3$ & Single & Eight \\
$\mathrm{BC}_{1} 80 / \# 5$ & Double & Six \\
$\mathrm{BC}_{1} 80 / \# 8$ & Double & Eight \\
$\mathrm{BC}_{1} 80 / \# 9$ & Single & Nine \\
$\mathrm{BC}_{1} 80 / \# 10$ & Double & Eight \\
$\mathrm{BC}_{1} 80 / \# 11$ & Single & Six \\
$\mathrm{BC}_{1} 80 / \# 12$ & Double & Twelve \\
\hline
\end{tabular}

The genomic in situ hybridisation technique developed was able to distinguish parental chromosome sets in both interphase and metaphase preparations of the $\mathrm{BC}_{1}$ hybrids. Unlabelled $E$. guineensis DNA used as block (Anamthawat-Jonsson and Heslop-Harrison, 1992) increases the specificity of probing. Due to high genome homology between both species, E. guineensis DNA block used were 120 $\mu \mathrm{g}$ for the backcross individuals. The blocking DNA hybridised to the sequences common in the blocking DNA, probe DNA and chromosomal DNA in situ, thereby leaving mainly species specific sequences as sites for labelled probe hybridisation (Orgaard and Heslop-Harrison, 1994). To discriminate more distantly related species, the use of blocking DNA is often unnecessary (Schwarzacher et al., 1989). For more closely related species sharing the same genome, e.g. Hordeum vulgare and H. bulbosum, or Secale cereale and S. africanum, addition of unlabelled blocking DNA is essential. This also applies to E. oleifera and E. guineensis, indicating relatedness
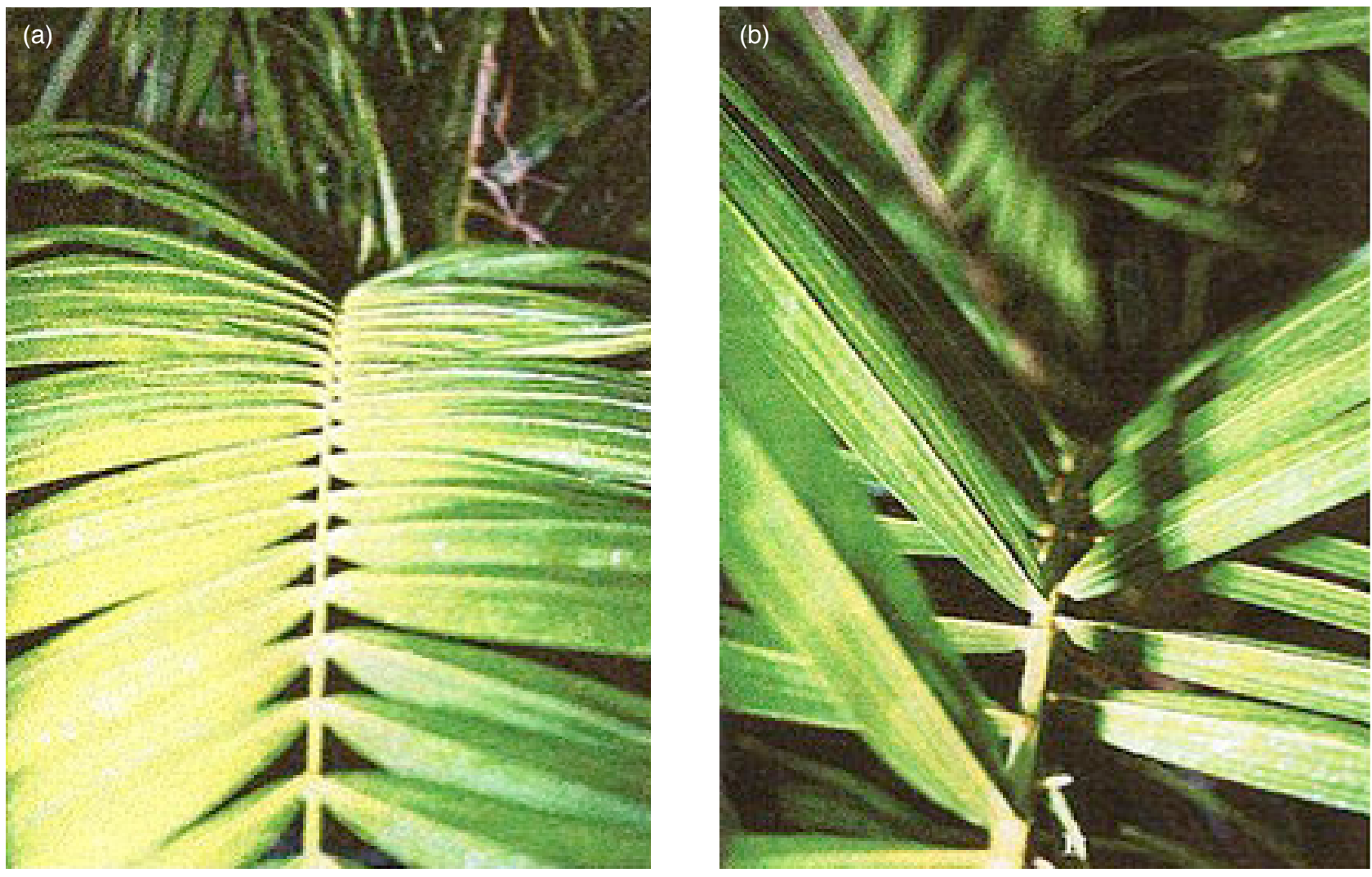

Figure 2. Horizontal view showing (a) E. oleifera with single plane leaflet arrangement and $(b)$ E. guineensis with double plane leaflet arrangement.

individuals showed either single or double leaflet plane arrangements. The data on backcrosses also showed no correlation between numbers of E. oleifera chromosomes introgressed with the inheritance pattern of leaflet arrangements. of the two species where Hardon and Tan (1969) have also reported their relatedness based on the morphology, cytology, ability to hybridise, and exhibit hybrid vigour. Cytogenetic studies showed normal chromosome pairing at pachytene in 
the OxG hybrids except for occasional unpaired chromosome segments. Generally no inversions, deficiency loops or translocation configurations were observed (Hardon and Tan, 1969).

\section{CONCLUSION}

Interspecific hybrid breeding is important for combining the good traits present in E. oleifera and E. guineensis into an alternative oil palm planting material that has partial resistance to bud rot. Through the GISH technique and in combination with other tools, oil palm breeders will be able to select for backcross one palms that contain the desirable composition of E. oleifera chromosomes or perhaps detect recombinant chromosomes for further backcrossing programmes. Since the screening can be done at the nursery stage, the land area required to plant the selected backcross materials will be reduced. In so doing, the duration of backcross breeding programmes would also be reduced significantly.

\section{ACKNOWLEDGEMENT}

We thank the Director-General of MPOB for permission to publish this article. We also would like to thank Dr Cheah Suan Choo and Mukesh Sharma for their contribution to the work reported in this article. The authors are grateful to the Malaysian government for funding this project under IRPA number 01-04-03-0025.

\section{REFERENCES}

ANAMTHAWAT-JONSSON, $\mathrm{K}$ and BODVARSDOTTIR S K (1998). Meiosis of wheat x lymegrass hybrids. Chromosome Research, 6: 339-343.

ANAMTHAWAT-JONSSON, $\mathrm{K}$ and HESLOPHARRISON, J S (1992). Species specific DNA sequences in the Triticeae. Hereditas, 116: 49-54.

ANAMTHAWAT; JONSSON, $\mathrm{K}$ and SCHWARZACHER, T; LEITCH, A R; BENNETT, M D and HESLOP-HARRISON, J S (1990). Discrimination between closely related Triticeae species using genomic DNA as probe. Theoretical and Applied Genetics, 79: 721-728.

DELLAPORTA, S L; WOOD, J and HICKS, J B (1983). A plant DNA minipreparation: Version II. Plant Molecular Biology Report, 1: 19-21.

HARDON, J J and TAN, G Y (1969). Interspecific hybrids in the genus Elaeis I. Crossability, cytogenetics and fertility of F1 hybrids of $E$. guineensis x E. oleifera. Euphytica, 18: 372-379.

HESLOP-HARRISON, J S; LEITCH, A R; SCHWARZACHER, $\mathrm{T}$ and ANAMTHAWATJONSSON, K (1990). Detection and characterization of $1 \mathrm{~B} / 1 \mathrm{R}$ translocations in hexaploid wheat. Heredity, 65: 385-392.

KUSHAIRI, A; SINGH, R and ONG-ABDULLAH, M (2017). The oil palm industry in Malaysia: Thriving with transformative technologies. J. Oil Palm Res. Vol. 29(4): 431-439.

KWON, M-J; RAMZAN, F; AHN, Y-J; HWANG, Y-J; KANG, Y-I; KIM, C-K; YOUNIS, A and LIM, K-B (2017). Chromosomal analysis of Lilium longiflorum x Asiatic hybrids using GISH (genomic in situ hybridization). Horticulture, Environment, and Biotechnology, 58(6): 591-600.

MADON, M; CLYDE, M M and CHEAH, S C (1998). Cytological analysis of Elaeis guineensis and Elaeis oleifera chromosomes. J. Oil Palm Res. Vol. 10(1): 6891.

MADON, M; CLYDE, M M and CHEAH, S C (1999). Application of genomic in situ hybridization (GISH) on Elaeis hybrids. J. Oil Palm Res. (Special Issue): 7480 .

MEUNIER, J; VALLEJO, G and BOUTIN, D (1976). L'hybride E. melanococca x E. guineensis et son amelioration. Oleagineux, 31: 519.

OBASOLA, C O; OBESESAN, I O and OPUTE, F I (1976). Breeding of short-stemmed oil palm in Nigeria. Proc. of the International Agriculture Oil Palm Conference. Kuala Lumpur, 26-28 May.

ORGAARD, M and HESLOP-HARRISON, J S (1994). Investigations of genome relationships between Leymus, Psathyrostachys and Hordeum inferred by genomic DNA: DNA in situ hybridization. Annals of Botany, 73: 195-203.

RAMZAN, F; YOUNIS, A and LIM, K-B (2017). Application of genomic in situ hybridization in horticultural science. International J. Genomics, 2017: Article ID 7561909. 12 pp.

SCHWARZACHER, T; LEITCH, AR; BENNETT, MD and HESLOP-HARRISON, J S (1989). In situ localization of parental genomes in a wide hybrid. Annals of Botany, 64: 315-324.

SINGH, R; ONG-ABDULLAH, M; LOW, E T L; MANAF, M A A; ROSLI, R; NOOKIAH, R; OOI, L C L; OOI, S E; CHAN, K L; HALIM, M A; AZIZI, N; NAGAPPAN, J; BACHER, B; LAKEY, N; SMITH, 
S W; HE, D; HOGAN, M; BUDIMAN, M A; LEE, E K; DESALLE, R; KUDRNA, D; GOICOECHEA, J L; WING, R A; WILSON, R K; FULTON, R S; ORDWAY, J M; MARTIENSSEN, $\mathrm{R} A$ and SAMBANTHAMURTHI, R (2013). Oil palm genome sequence reveals divergence of interfertile species in old and new worlds. Nature, 500 (7462): 335-339.

TORRES, G A; SARRIA, G A; MARTINEZ, G; VARON, F; DRENTH, A and GUEST, D I (2016). Bud rot caused by Phytophthora palmivora: A destructive emerging disease of oil palm. Phytopathology, 106: 320-329.

YANG, C; ZHANG, H; CHEN, W; KANG, H; WANG, Y; SHA, L; FAN, X; ZENG, J and ZHOU, $Y$ (2017). Genomic constitution and intergenomic translocations in the Elymus dahuricus complex revealed by multicolor GISH. Genome, 60 (6): 510517 